\title{
Challenges of future energy landscapes in Germany - a nature conservation perspective
}

\author{
Jens Ponitka* and Sarah Boettner
}

\begin{abstract}
Background: The energy transition in Germany is characterized by a rapid growth of renewable energy and infrastructure. In order to reduce the impact of humans on the climate system, a more ambitious development of renewable energies is needed. In addition, nature and natural resources must be protected. At the same time, the increasing use of renewable energies leads to impacts on nature conservation aspects, in particular on landscapes, species, and habitats. Therefore, renewable energy systems also affect the protection of biodiversity. Conflicting objectives between the need for renewable energies and their impact on nature and landscape have to be considered equally and as early as possible.
\end{abstract}

Methods: The article follows an interdisciplinary approach that combines an administrative with a research perspective. First, the energy transition as a national transformation process and challenges due to the expansion of renewable energies with regard to nature conservation and landscape management are presented. The analysis of existing literature identifies key factors for a sustainable energy transition such as land availability, landscapes, and impacts on species and habitats. Examining the most affected nature conservation aspects from an administrative perspective, we highlight selected research projects, derive future research demand, and discuss possible approaches to enhance the integration of nature conservation into the energy transition.

Results: In addition to the need for climate protection efforts, the energy transition further has to preserve biological diversity, as well as characteristic features and the beauty of nature and landscape. Numerous energy transition stakeholders face the challenge of integrating nature conservation and landscape management requirements into research projects, strategic planning, and approval procedures. Based on the dynamic development of renewable energies in Germany and the objectives of nature conservation, we describe key challenges and identify future research demands from an administrative and scientific point of view. Current research projects, the impacts of renewable energy generation, and existing approaches to minimize negative effects on nature and landscape are taken into account.

Conclusions: We conclude that nature conservation aspects in general (biodiversity and landscape) have to be better integrated in the energy transition. Therefore, research, technology development and preference, civil participation, a critical discussion, and academic debate are essential elements for a nature-compatible expansion of renewable energies.

Keywords: Nature conservation, Energy transition, Landscape, Energy landscapes, Landscape transformation, Renewable energy

\footnotetext{
* Correspondence: Jens.Ponitka@bfn.de

Department of Nature Conservation and Renewable Energy, German Federal

Agency for Nature Conservation-BfN, Alte Messe 6, 04103 Leipzig, Germany
}

(c) The Author(s). 2020 Open Access This article is licensed under a Creative Commons Attribution 4.0 International License, which permits use, sharing, adaptation, distribution and reproduction in any medium or format, as long as you give appropriate credit to the original author(s) and the source, provide a link to the Creative Commons licence, and indicate if changes were made. The images or other third party material in this article are included in the article's Creative Commons licence, unless indicated otherwise in a credit line to the material. If material is not included in the article's Creative Commons licence and your intended use is not permitted by statutory regulation or exceeds the permitted use, you will need to obtain permission directly from the copyright holder. To view a copy of this licence, visit http://creativecommons.org/licenses/by/4.0/ The Creative Commons Public Domain Dedication waiver (http://creativecommons.org/publicdomain/zero/1.0/) applies to the data made available in this article, unless otherwise stated in a credit line to the data. 


\section{Background}

The energy transition as a national transformation process with respect to nature conservation and landscape management

Landscapes have been constantly changing by anthropogenic influences. However, the pace of changes increased in the past few years, partly because of the energy transition in Germany. Large agricultural areas were transformed into energy landscapes by new energy infrastructures like wind turbines [1]. There are several reasons for accelerating the transition to a more sustainable energy system by the development of renewable energy (RE): (1) the need for climate change protection due to ongoing climate change, (2) the limited availability of fossil fuels, and (3)-especially for Germany-the phase-out of nuclear energy by 2022. The German energy transition goals were declared in 2010 in the energy concept [2] and were specified for the electricity sector in the German Renewable Energy Act (EEG) [3]. The EEG serves as the legislative basis to reach the RE goals of 5 to $60 \%$ by 2035 and at least $80 \%$ by 2050 . This resulted in a considerable infrastructure and area demand and hence caused considerable changes in the landscape. The energy transition will continue to have impacts on nature conservation concerns in the future. On the other hand, Germany has to apply national and international legislation and has to take agreements into account, for example the Convention on Biological Diversity [4].

Against the background of the ambitious national RE goals, the transformation process of the German energy transition just started. In 2018, a share of only $16.6 \%$ of gross final energy consumption was met by energy produced from renewable energy sources (RES) [5] in Germany. Therefore, it is necessary to be aware of the future challenges that include the conservation of biodiversity and social challenges such as energy consumption and the acceptance of renewable energies. Climate change has a direct impact on biodiversity and requires enhanced protection of the natural environment [6]. From a specific nature conservation point of view, potential changes of the landscape and negative effects on species and habitats by RE need to be incorporated in order to minimize negative impacts.

Today, the provision of RE in Germany focuses primarily on wind turbines, photovoltaics (PV), and biomass plants [5]. These technologies need to be evaluated in the context of their respective impacts on nature and landscape, their spatial needs, and possible future relevance. RE within the electricity sector are the current main drivers of the energy transition. In 2018, RE provided $37.8 \%$ of the gross electricity consumption with a strong development in the past decade [5]. The role of electricity as a source of energy will further increase, especially in regard to the rising relevance of sector coupling [7]. Without a drastic reduction of energy consumption, a sustainable development of RE in compliance with nature conservation cannot be realized
[6]. Achieving the overall energy transition and low carbon future goals may represent further challenges for nature conservation and its governance, regulation, and research demands.

Many negative impacts on the landscape and nature conservation aspects arise because of the increasing use of RE technologies characterized by a high land demand. Therefore, the article discusses the main technologies wind energy, PV, and biogas, which are currently in the focus of political discussion.

Within the electricity sector today, wind energy is the largest RES in Germany [5]. The number of wind turbines tripled between 2000 (9359 units) and 2018 (29,213 units) [8]. With around one-tenth of the wind turbines installed worldwide [9], Germany has a high density of wind turbines compared to other countries, despite its comparatively small size. As an example, Fig. 1 visualizes landscapes in Germany facing major landscape transformation since 1996. These regions are characterized by a relatively high density of RE. In particular in the northern parts of Germany, landscapes have changed rapidly as a result of the expansion of wind power plants. In some regions with low population density, extensive agricultural landscapes and good wind conditions, large wind farms already dominate the landscape. This applies especially to large parts of Lower Saxony, Schleswig-Holstein, Saxony-Anhalt, Brandenburg, and Mecklenburg Western Pomerania (Fig. 1). The energy transition is not finished yet; therefore, the landscape changes will intensify in the future.

In contrast, electricity supply from biomass, mainly biogas, is primarily focused in the northwestern and southern parts of Germany [10-12]. In addition to the construction of biogas plants, landscape changes in these regions can be explained by the extended cultivation of monocultures such as corn along with negative side effects like loss of grassland. In 2018, a total of 1.35 million hectares of substrates were specifically cultivated for biogas production, which represents about $12 \%$ of the arable land in Germany [13].

Except for isolated, but large-scale solar farms in the southeast of Brandenburg, the highest concentration of PV systems with respect to landscape changes can be found in southwestern Germany (see Fig. 1). According to [14] the different types of PV systems, like PV roof-mounted systems or solar farms on agricultural land or along transport infrastructure can be explained by the relevant regulatory framework and changing restrictions. From a nature conservation perspective, it is important to save as much open space as possible. The development in Germany was different (see Table 1). The total installed PV capacity increased from about $2.9 \mathrm{GW}(2.2 \mathrm{TWh})$ in 2006 to more than 45 GW (44.8 TWh) in 2018. In the same period, the share of less favorable solar farms increased from 5.4 to $27.8 \%$. It cannot be ruled out that solar farms are built on ecological 


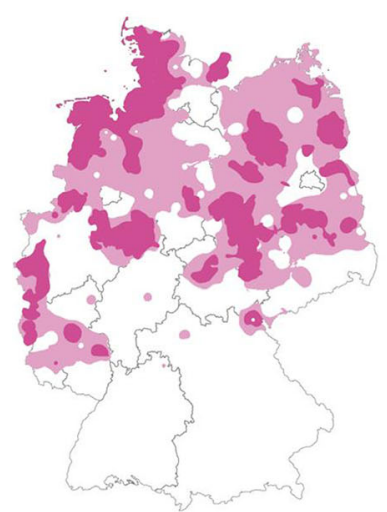

Wind energy plants

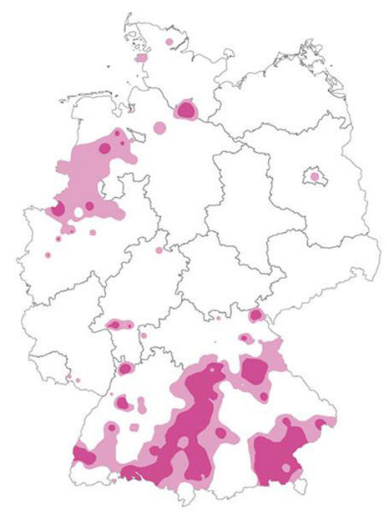

Biomass energy plants

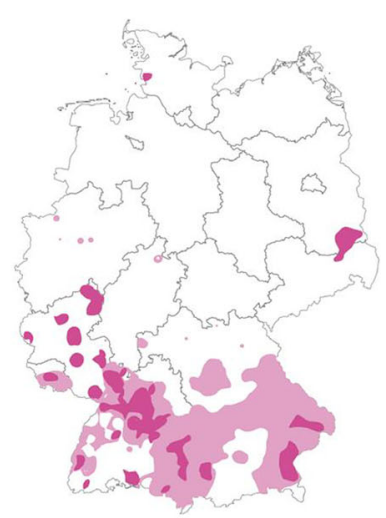

Solar farms

Fig. 1 Landscapes in Germany with high (pink) and very high (purple) landscape transformation since 1996 induced by plant installations and land demand of different renewable energy sources (adapted from [10])

sensitive agricultural land. The need for governance is obvious. Restrictions, especially regarding spatial categories exempt from financial funding, were gradually implemented by subsequent versions of the EEG [14, 15]. In addition, it is essential to promote PV roof systems more than solar farms on agricultural land.

Another aspect related to the energy transition, especially within the electricity system, is transport of electricity. The need for more overhead power lines may have increasing impacts on landscapes and nature conservation aspects as well [16].

It can be summarized that landscape change in Germany and the respective impairment of the visual appearance and recreational function is not only local or site-specific, but a regional and large-scale phenomenon. Combining local information about different RE, it is possible to identify energy landscapes (e.g., wind energy or bioenergy dominated landscape, Fig. 1). Energy landscapes were even proposed as a new category of cultural landscape type [1].

Besides land demand and landscape changes, a wide range of further impacts and potential conflicts with natural dynamics of ecosystems or biodiversity occur for different RE types $[6,17,18]$. Major conflicts, especially for wind energy and bioenergy, arise from effects on habitats and species. The movements of the rotor blades of a wind turbine can lead to species disturbances,

Table 1 Evolution of PV installations, PV electricity production, and solar farms in Germany (based on [14])

\begin{tabular}{lllll}
\hline & 2006 & 2009 & 2012 & 2018 \\
\hline PV capacity installed [MW] & 2864 & 10,545 & 32,964 & 45,327 \\
Electricity production [TWh] & 2.2 & 6.6 & 26.2 & 44.8 \\
PV capacity of solar farms [MW] & 155 & 1324 & 8368 & 12,618 \\
Share of solar farms [\%] & 5.4 & 12.6 & 25.4 & 27.8 \\
\hline
\end{tabular}

barrier effects, and collisions of birds and bats. On the one hand, the need for substrate cultivation, in particular corn, for bioenergy production leads to direct impacts such as land use change or habitat loss. Secondly, indirect effects like a subsequent loss of biodiversity [19] can occur by changes in cropping or harvesting intensity. Land is a scarce resource and RE like PV, can have a negative impact on habitats by using large areas of grassland [19]. Other technologies like hydropower or geothermal energy may also adversely affect nature conservation. But due to the small share in renewable gross electricity consumption (total of around $8 \%$ in 2018 [5]) and limited potentials, we exclude these technologies from further examination in this article.

\section{Nature conservation and renewable energies}

The energy transition and the related structural changes of our economic and energy system are necessary and will have effects on humans, nature, and landscape. For a low carbon future, an ambitious development of RE is necessary. This should be realized as sustainable as possible, both in terms of its basic orientation (e.g., technology preference, sectoral energy goals) but also of its implementation. Germany, as part of the international community, has made a commitment to reduce anthropogenic interference with the climate system [20]. At the same time it has set ambitious targets to protect biodiversity and thus secure the foundations for human and natural life $[4,21$, 22]. A sustainable energy transition therefore needs to consider all target dimensions of the German energy concept such as security of supply, economic viability, and an effective protection of the environment and climate [2]. So the environment, environmental compatibility, and the preservation of biodiversity need to be considered adequately within the energy transition [6]. 
The achievement of a nature-compatible energy transition is a major objective of the BfN [6]. Among other tasks, $\mathrm{BfN}$ is responsible for science-based policy consultation and the implementation of RE research with respect to nature conservation to gain knowledge for policy, federal states, users, and for the general public. BfN aggregates research results, develops further research questions, and transfers results into political options for action [23]. This insight into administrative and political perspectives of a nature-compatible energy transition is one of the motivations of the authors to highlight and exemplarily discuss this complex topic for selected RE technologies and thematic fields.

The results of the article derived from the selected conflicts and RE examples from the literature could be transferred to other high population density countries. In this regard, the article does not claim to be exhaustive in all aspects of nature conservation and the development of RE and their relations. Rather, it provides a comprehensive overview of selected topics as a starting point for discussion and better integration of nature and landscape conservation into energy transition efforts and research programs.

\section{Approach and structure of the article}

Based on the conflicts of RE development with regard to nature conservation [19], this article presents the challenges resulting from a literature review. The central challenges of land availability, landscape, and consequences for species and habitats are analyzed for selected RE technologies. We discuss the tension between administrative and specific research perspectives for current research projects and their results as well as future research questions. Based on the discussion, we suggest possible approaches to enhance the integration of nature conservation into the energy transition. The results and suggested approaches represent only a part of the solution. Since the authors work at a federal agency (BfN) as one of the many nature conservation stakeholders, the article also reflects the perspective of a political actor, but nevertheless outlines a combination of literature and science with a governmental and policy consultation point of view.

\section{Results}

\section{Current and future challenges between nature} conservation and renewable energy development

The worldwide promotion of renewable energies for a low-carbon future resulted in enormous increases in efficiency and cost reductions, which led to a large increase in decentralized RE plants in Germany. On the one hand, there is a need for a dynamic development of RE, but on the other hand, several challenges for nature and landscape conservation occurred over the years $[6,19]$.
Besides species and habitats, landscapes are legally protected according to $\$ 1$ of the German Federal Nature Conservation Act (BNatSchG) [24] in their diversity, character, beauty, and recreational value. The transformation of the landscape by RE infrastructure reveals conflicts to these protected goods. Despite the fact of a fundamental acceptance of the energy transition [22, 25, $26]$, there are acceptance problems among the general public and local residents [27], most likely as a result of landscape changes [12]. Internationally, Germany is a relatively small and densely populated country. Available land is limited and an important resource for various interest groups. RE, despite their advantages, have a relatively high land demand for the same energy output compared to fossil or nuclear systems [28, 29]. Large central power plants need to be replaced gradually by a large number of decentral RE systems. This results in the energy transition becoming more visible within the landscape. In contrast to open pit mining, this does not necessarily result in permanent landscape change due to the limited operation time of RE technologies of around 20 years and the possibility for the removal of infrastructure. Besides the ecological dimensions, a further challenging issue is the very individual and subjective perception of landscape [30]. The human-induced transformation of the landscape leads to various challenges. These include the region-specific definition of historical cultural landscapes, their weighting in spatial planning, and the evaluation of existing data. People are affected by changes in familiar scenery and their home. RE plants invade the private environments, along with measurable changes in aesthetic quality and value of landscapes.

The impact of RE on landscapes can lead to a monotonous or fundamental change in the known landscape. There is also a risk that the protected goods' diversity, uniqueness, and beauty of nature and landscape [24] will be impaired by the dominance of new infrastructures such as wind turbines. Legal regulations often challenge the planning authorities in the valid assessment of landscape because the terms first have to be defined region-specific in order to carry out a landscape assessment [31]. This implies that the energy transition and the creation of energy landscapes need to be communicated and organized at an early stage in cooperation between politicians, planners, the competent authorities, and residents.

Landscape change represents one of many conflicts. The restricted availability of area is an emerging concern [32]. Various nationwide studies [33-35] calculate technical potentials, especially for wind energy. According to these studies, Germany still has development potential of up to $13.8 \%$ of the of the country's territory [33]. Considering more nature conservation restrictions like different types of nature conservation areas and protected goods, low conflict area potentials are calculated with 
less than 2\% [34] of the country's territory. On the other hand, no specific area target or locations for RE are yet determined on the national level. Some federal states defined their own energy or land area targets for wind energy development (e.g., about $2 \%$ of the federal state area of Hessia) which are usually a subject of regional planning. These special designated areas for wind energy development currently cover only $0.9 \%$ [36] of the national territory, while having large landscape effects. The current development and speed of target achievement are also very different among the federal states due to environmental inventories and overall regulations. Nature conservation is regulated by the individual federal states, which also leads to the situation that the conflicts and handling of nature conservation and landscape issues vary between the federal states. For example, the regional planning for specific wind energy zones or priority areas is subject to varying regulations in each federal state in Germany [37]. The complexity of the different rules in the federal system complicates finding common, nationwide solutions.

In contrast to area demand and landscape conservation issues, one of the crucial topics of RE development today, especially for the project developers and planning and approving authorities, is species protection. The handling of bird and bat collision risks within the context of wind energy projects is an ongoing challenge for example in approval procedures but also legal proceedings. BfN as a federal authority supports a naturecompatible RE development by funding research projects and transferring the results into political options for action and manageable solutions [23].

In order to get an idea of nature conservation challenges, possible solutions and especially future landscape needs, we have analyzed scenario studies. Numerous studies with various energy scenarios until the year 2050 [38-40] were carried out to support energy transition decisions. The studies are characterized by different assumptions and used models and focus on different objectives like climate change mitigation, RE development, sector coupling, nuclear phase-out, fossil fuel (coal) phase-out, or nature conservation. Table 2 shows excerpts of four scenarios compared to the status quo (2018). Depending on the scenario, the energy demand in 2050 is between 1211 TWh (scenario C) and 1864 TWh (scenario D). The energy demand is always assumed to be lower than today (2018, $2578 \mathrm{TWh})$. The importance of gross electricity consumption differs between about 440 TWh (scenario A) to 1139 TWh (scenario D). Most scenarios result in PV and wind energy as the main RE, while scenario A determined biomass and wind energy. Scenarios can provide orientation on future technology preferences and assess potential consequences. Scenario D [29] is oriented to a naturecompatible development. A large number of PV roof systems and the higher electricity consumption because of increasing electrification represent the difference to the other scenarios and the status quo. Decision makers need to be aware of the different options, but also the restrictions. For example, commercial decision criteria were not included in all studies.

Based on the selected scenarios (Table 2) and the German expansion targets for renewable energies [2], a future increase in the number of installations, especially PV and wind power plants, is expected. Stronger effects of these technologies on nature conservation and landscapes need to be anticipated as early as possible.

\section{Specific fields of interest-ongoing research and research demand}

Some overall objectives that are currently of special relevance in nature conservation and $\mathrm{RE}$ expansion are nature and landscape themselves, as well as the availability of nature-compatible area for RE development, and monitoring. These objectives are not only the basis of ongoing research and future research demand but also

Table 2 Overview of key parameters of different energy scenarios for Germany for 2050 in comparison with status quo (own representation based on the study results)

\begin{tabular}{|c|c|c|c|c|c|c|}
\hline Scenario & $\begin{array}{l}\text { Source/study } \\
\text { year }\end{array}$ & $\begin{array}{l}\text { Reference } \\
\text { year }\end{array}$ & $\begin{array}{l}\text { End energy } \\
\text { demand [TWh] }\end{array}$ & $\begin{array}{l}\text { Share of renewable energy } \\
\text { in end energy demand [\%] }\end{array}$ & $\begin{array}{l}\text { Gross electricity } \\
\text { consumption [TWh] }\end{array}$ & $\begin{array}{l}\text { Main RE (in gross } \\
\text { electricity generation) }\end{array}$ \\
\hline Status quo & {$[5]$} & 2018 & 2572 & 16.6 & 600.9 & $\begin{array}{l}\text { 1. wind } \\
\text { 2. PV }\end{array}$ \\
\hline "Scenario A" (original title: IA) & {$[41] / 2010$} & 2050 & 1451 & 59.6 & 440.6 & $\begin{array}{l}\text { 1. biomass } \\
\text { 2. wind }\end{array}$ \\
\hline "Scenario B" (original title: 2011C) & {$[42] / 2012$} & 2050 & 1416 & 59.1 & 534 & $\begin{array}{l}\text { 1. wind } \\
\text { 2. PV }\end{array}$ \\
\hline "Scenario C"(original title: KS 95) & {$[43] / 2015$} & 2050 & 1211 & 96.4 & 779 & $\begin{array}{l}\text { 1. wind } \\
\text { 2. PV }\end{array}$ \\
\hline "Scenario D" (original title: II) & {$[29] / 2018$} & 2050 & $\begin{array}{l}1362^{(1)} \text { to } \\
1864^{(2)}\end{array}$ & $100^{(3)}$ & 818 to 1139 & $\begin{array}{l}\text { 1. PV } \\
\text { 2. wind }\end{array}$ \\
\hline
\end{tabular}

(1)based on "very ambitious" energy demand reduction assumptions, (2) based on "ambitious" energy demand reduction assumptions, ${ }^{(3)}$ target scenario: The study compares energy demand with the goal of providing $100 \%$ by RE 
represent key topics of the work of the BfN through providing a link between nature conservation needs and a nature-compatible RE development.

Given the status quo of RE, knowledge of potential negative effects and probable future RE development, there are of course questions to be answered, such as how to measure and monitor the effects of RE on nature and landscape, which trends will have the largest influence, or which species protection or control measures need to be implemented. These overall objectives and basic research needs lead to the following key topics of nature conservation especially in relation to the development of renewables [44]:

- Landscapes and renewable energies,

- Effects on natural environments and habitats,

- Species protection,

- Description of management approaches, and

- An adequate investigation and monitoring of the positive and negative effects on nature and landscape in detail.

The research projects at the BfN $[6,44]$ address large parts of these key topics. The spatial impacts of RE and the scarcity of conflict-free area especially in Germany is obvious. Therefore, the prospective RE mix should pursue the expansion of PV (especially on built-up areas), as well as wind energy, while continuing the development of highly efficient and sustainable technologies. Due to limited nature-compatible areas, it is also crucial to focus further construction on technologies with high space efficiency. Additionally, technical developments can be expected, especially for PV and wind energy. Significant efficiency gains are possible for PV [14], resulting in further naturecompatible applications at existing urban or transport infrastructures. In addition to support and development of roof-mounted PV systems, there are new future prospects such as PV integration in building facades or even in traffic routes. From a nature conservation perspective, these solutions are conflict-free since they do not have to be located in the open landscape and thus relieve the "free" landscape.

The tasks and objectives of nature conservation and landscape management are specified for the respective planning area by landscape planning. A main task of preventive landscape planning is the qualified examination of landscapes and cultural landscapes. In addition, landscape planning provides important information for a landscape-friendly and sustainable RE expansion. For example, a nationwide landscape evaluation method [45] was developed, which can be used to evaluate landscapes and landscape features at a regional level. So far, this nationwide assessment provides only a basis for a regionspecific landscape assessment considering the need for individual scaling. To guarantee a nature-compatible integration of RE into the landscape, a detailed landscape assessment and planning are required. In this landscape context, the following fields of action are recommended [31]:

- Consideration of cultural landscapes and landscapes by qualification of landscape master plans and landscape plans,

- Inclusion of comprehensive energy concepts in regional plans,

- Development of a landscape contribution to energy concepts.

Within the planning process, effects of site selection and approval procedures on nature conservation aspects are partly addressed, such as the definition of certain standards (like landscape assessment). The different science-based approaches including nature conservation (e.g., sensitivity of species, field survey methods, and evaluation standards) need to be developed or consequently improved by using better input data. New research results have to be integrated into existing guidelines, but also have to be harmonized between the federal states.

It is important to provide a solid data pool by monitoring negative effects. Ideally, nationwide data for RE installations and the relevant protected goods will be made available. As a starting point for minimizing negative impacts, a GIS compilation of RE plants in Germany is already available [46]. In our view, transdisciplinary approaches (ecology, technology, social sciences) are necessary to adequately address the complex impacts on nature and landscape.

On such a monitoring basis, the improvement of naturecompatible guidance documents and appropriate instruments, like planning and improving standards for species protection will be feasible. To manage nature conservation challenges, a wide range of approaches already exist. For example, the implementation of suitable regional planning methods enables the avoidance of sensitive habitats or regions (like protected areas). In addition to regional planning, more specific species protection demands need to be handled within approval procedures. For example, collision-sensitive species like the Red Kite [Milvus milvus] need to be adequately considered [47-49]. Especially for species protection, it is important to continuously include the latest scientific findings in guidelines or decrees and approval procedures. Good approaches can already be found, like the widely implemented distance recommendations to collision-sensitive species [48] or the definition of major frequency areas of the Red Kite. For example, major frequency areas were defined for Saxony-Anhalt [50] and were applied in the official guidance document for species protection [51]. Minimizing collision risks of birds and bats by developing and applying effective evidence-based mitigation measures [52] need to be further pursued. 
The following chapters represent some more detailed aspects of three key research topics and projects [44]: Visible landscapes, Scenarios, and Monitoring.

\section{Visible landscape}

The energy transition, especially the expansion of wind turbines, solar farms, and biogas plants, is reflected within landscapes and cause modifications-of different scale-to the traditional landscape organization and image. In particular, biomass production and the associated large-scale cultivation of maize and rape lead to a monotonous visual landscape. By considering the landscape-aesthetic consequences of the energy transition and its current handling in planning and approval procedures, proposals and recommendations have been developed to further elaborate common landscape assessment methods [31]. At the same time, these should take account of the fact, that the perception of landscapes and landscape changes take place individually and very differently. Often landscape arguments are used implicitly within campaigns against wind energy projects [53]. Against this background, the subject of a research project [12], for example, was to consider the possibilities of a participatory form of landscape aesthetic evaluations in particular and of planning procedures in general.

Other research projects [54, 55], which provide a methodological approach to GIS-based landscape image assessment, achieve similar results. Validating the developed model by using nationwide data enables an optimized future planning by including the landscape and achieves a higher acceptance by society [55]. More methodological approaches and recommendations are principally available to take landscapes into account for example within planning procedures $[56,57]$ or as tools for landscape assessment [45]. These different approaches as part of an overlay may help to better considering the quality and value of landscapes. This approach still needs to be validated before concrete practical results can be achieved.

\section{Monitoring}

The measurement of nature conservation issues, for example, national impacts of RE on habitats, species, or landscapes is a challenging task due existing knowledge and data gaps. For example, it has been shown that birds $[58,59]$ and bats $[60]$ collide with rotor blades of wind turbines. However, it is not clear, what effects these local collisions may have on regional or national species populations. Besides investigating best practices, a better assessment of impacts on biodiversity is needed. Moreover, methods for cumulative assessment of effects on species and habitats can be developed or improved by analyzing monitoring data.

Therefore, it is important to collect comprehensive RE spatial data and data about affected species (e.g., population-level effects, species displacement, mortality data of species) for trend analyses. In this way, it is possible to take corrective actions, like aid programs for species [61], as soon as negative effects can be observed.

A research project, that developed nationwide monitoring approaches of the effects of renewables in the electricity sector on nature and landscapes [62] aims at identifying and analyzing existing data, data gaps, and developing practicable indicators. Three main monitoring fields were identified. First, it is important to monitor the target achievement of a nature-compatible energy transition, for example the achievement of energy consumption reduction (as it was formulated by [63]). A second monitoring aspect derived from the research project [62] is the spatial distribution of RE plants [46] and power lines [16] with respect to, for example, nature conservation areas or sensitive forests. The third monitoring field is direct effects on legally protected goods like animals or populations. Further research is clearly necessary because of missing data and practical knowledge about specific population effects. As long as there are still knowledge gaps, planning and steering of RE infrastructure need to be performed with a precautionary approach. High nature conservation requirements should be claimed as long as there is no exculpatory evidence.

\section{Scenario research}

Monitoring the effects of RE development on nature conservation aspects can support short-term management of the RE expansion. In contrast, scenario research helps to assess future trends and possible developments [64]. In order to be in a position to early address nature conservation into the mid-term and long-term energy transition decisions, scenario studies are one way to better understand the interaction between future energy demand, technology development, and nature-compatible RE potentials.

A nature conservation oriented scenario study [29] shows that the German energy demand in 2050 could potentially be supplied to $100 \%$ by RE installations in Germany in a nature-compatible way. This, of course, contradicts the slow progress in the overall replacement of fossil fuels. To calculate this scenario, certain assumptions were made, for example drastically reduction of energy demand, very high efficiency of RE, a high degree of electrification, focus on PV roof systems, and only using the lowest risk areas for wind energy. The practical implementation of such a scenario would be very challenging. The study can be seen as a starting point for discussion and shows preliminary options to optimize the energy transition at an early stage (sectoral energy targets, technology funding) from a nature conservation perspective. Similar results can be found in a study from WWF [65]. It uses a different methodical approach and 
assumes higher shares of wind power than [29] but also higher proportions of installed PV roof systems than other energy system scenario studies. Therefore, the objective of scenario studies should be noted within energy transition discussions.

In contrast to the long-term orientation until 2050 with the described assumptions and spatial approach in [29], a mid-term scenario study until 2035 [66] was developed considering nature conservation aspects by integrating a nationwide comparative assessment of risk levels. With a modified spatial model, nationwide wind energy sites and the dependencies between naturecompatibility (conflict risk rating), regional energy demand, and wind conditions are specifically analyzed. Results of the study indicate that for lower-specific conflict risks, the energy demand can be covered by a relatively small additional demand for wind turbines [66]. Implementing nature conservation requirements on a national level by considering local characteristics may lead to a higher number of wind turbines. This would be in conflict with objectives like the reduction of landscape impairment but represent a greater amount of avoided conflict risks.

A key factor of RE scenarios that are more nature conservation oriented is availability of areas with low risks for nature conservation aspects. Area potentials and energy provision from RES are highly dependent on the assumptions and extent of nature conservation restrictions. It is important to know that national studies do not necessarily have impacts on the nature-compatible local RE development, because planning and authorization are regulated by the state governments or local authorities.

The different methods developed in the two nature conservation scenario studies $[29,66]$ provide the means to analyze trade-offs between relevant drivers, although further improvements like an overlay of the different conflict datasets are necessary for reliable and utilizable results. However, to identify the trade-offs and well balanced solutions, an assessment of the benefits and risks for nature conservation and RE expansion is needed. The scenario results can be used, for example, as a basis for scientific or political discussion or as an orientation to improve spatial planning, to develop naturecompatible RE expansion strategies, and to push technology development. As a good example, intermediate results from a scenario study [29] (see also Table 2) were used to formulate political statements on a conceptual, ministerial level (Federal Ministry for the Environment, Nature Conservation and Nuclear Safety) [63]. This statements include efficiency and energy saving (transport, heat, and electricity) as essential requirements, increased use of RE technologies on or close to buildings, careful development of wind energy using the optimum locations, and efficient use of bioenergy from residual and waste materials. The key statements of a naturecompatible energy transition were then communicated on this political level to enable and improve the integration of nature conservation aspects within the energy transition and thus reduce the effects on nature and landscape. These demands resulted in a publication of a special RE report [6] to further promote a naturecompatible energy transition in the context of $\mathrm{BfN}$ research.

\section{Discussion}

Renewable energies represent a necessary element within the energy transition efforts and a further spatial development is very likely. The potential negative effects of RE development and RE plant operation are principally known. On this basis, key elements for a naturecompatible energy transition can be formulated. There are still data and knowledge gaps that constitute nature conservation challenges on local (approval procedures, regional planning) to nationwide (RE goals, technology preference, funding) scales. In addition, natural processes or responses of species and populations often take long time or are difficult to monitor and to model. The integration of field study results into binding guidance documents also represents a challenge. This together complicates the prompt implementation of nature conservation requirements within the energy transition.

With many stakeholders of different competences being involved in nature conservation and RE development, energy transition is a challenging process that needs to be addressed in a joint dialogue and mutual understanding of stakeholders. A response to the complexity of environmental and social aspects of the energy transition is wellprepared information from additional research projects and active support in planning practice.

Therefore, our results indicate a need for an early, precautionary inclusion of nature conservation within the energy transition process with, for example, better spatially replicated data to include species protection and landscape management into overall energy goals and planning activities. For this reason, there is a need to continuously adapt the economic environment (incentive mechanisms), regulatory framework conditions (e.g., wind energy ordinances, species protection guidelines, determination of energy targets), and research topics [19].

\section{Conclusion}

The challenges of a substantive development of RE to tackle climate change and biodiversity loss are high. To achieve the two objectives, a nature-compatible implementation of the energy transition is needed by means of integrating biodiversity into national and federal policies for renewable energy mix. The article gives an overview of the major nature and landscape conservation 
topics for selected RE technologies by combining literature, selected research projects, and research demand with a perspective of an administrative actor. As one of the many nature conservation stakeholders in Germany, the $\mathrm{BfN}$ is responsible, among other tasks, for sciencebased policy consultation in the field of RE development $[23,44]$.

The analysis of published reports and research projects show that the strong increase of RE in a densely populated country like Germany led to conflicts with nature conservation, especially regarding landscape transformation, the availability of nature-compatible area, and effects on habitats and species. However, the energy transition has just started. In the future, we can expect an even more dynamic $\mathrm{RE}$ development and need for decentralized RE infrastructure. That potentially increases negative effects on nature and landscapes. The later we accelerate the renewable energy expansion, the faster the implementation has to be to reach the long-term climate goals. This would also increase the efforts to integrate nature and landscape into strategic and regional planning and approval procedures. Therefore, nature and landscape conservation issues need to be further investigated and then to be communicated, for example, as a nationwide concept of nature-compatible areas for wind energy combined with regional RE targets. Such a concept needs to be discussed with relevant experts and decisionmakers to meet a high level of acceptance within the present political framework. Currently, landscape planning evaluates the landscape quality of a region. In the future, landscape master plans could address wind energy plants. This would enable the definition of valuable landscapes, which could be included in the regional plan as excluded areas for wind energy and ensure preventive protection for the cultural landscapes. In this context, efficient participatory approaches or different types of energy production organization, such as energy cooperatives, may also enhance the local acceptance [27].

As area demand for RE is high and nature-compatible land is very limited, the need for an overall reduction of energy consumption and further efficiency gains is obvious and needs to be communicated and promoted. This would greatly minimize the impacts on land demand, landscapes, habitats, and species. Despite the challenge of reducing absolute energy demand, the energy transition and thus installing more RE infrastructure into landscapes have just started. For example, the selected research projects show that scenarios along with implementing a monitoring can help to identify and visualize the need for certain action (e.g., binding RE targets, supporting the most efficient and nature-compatible technologies) and to present options for the development of nature-compatible RE, for example the integration of energy landscapes into planning. Research and development projects already address the most crucial nature conservation and landscape aspects. Further research but also (political) dialog is needed because of the complexity and different competences of stakeholders. There is still a lack of data but also knowledge gaps. However, the available research results can already be interpreted and translated into practicable concepts (criteria for regional planning, standards for species protection, monitoring) for federal and local authorities, for example, to implement RE and nature conservation targets. This would enable the achievement of the most efficient land use and a nature-compatible steering of plants onto appropriate sites. Depending on the objective, for example, reducing the local impacts on species and habitats or improving the nationwide distribution of RE, a sustainable regional or national planning of RE could be an efficient approach. It is not impossible to translate and better communicate research results among different stakeholders and authorities. Practicable concepts need to be developed and coordinated. Negative impacts for example on certain species or habitats need to be consequently minimized by effective, site-specific measures. Finally, the importance of nature-compatible planning and optimal plant siting should be emphasized among relevant stakeholders.

\section{Abbreviations \\ RE: Renewable energy; EEG: Erneuerbare-Energien-Gesetz (German Renewable Energy Act); RES: Renewable energy sources; PV: Photovoltaics; BfN: Bundesamt für Naturschutz (German Federal Agency for Nature Conservation)}

\section{Acknowledgements}

Joint research on this paper has been undertaken in the context of the research focus on the inclusion of nature conservation within the energy transition in Germany, which the Federal Agency for Nature Conservation has placed or commissioned on behalf of the Federal Ministry for the Environment, Nature Conservation and Nuclear Safety (Bundesministerium für Umwelt, Naturschutz und nukleare Sicherheit-BMU). Further information can be found at [67]. This manuscript was greatly improved by valuable comments from Kathrin Ammermann (BfN). We thank Katharina Schilling and Dr. Georgia Erdmann for language editing and proofreading.

\section{Authors' contributions \\ The two authors drafted the different parts of the first version of this manuscript. SB and JP have contributed equally to the writing and contributed to the revising and finalizing of the article. The presentation preceding the paper on the same topic at the UFZ Energy Days was given by JP. All authors read and approved the final manuscript.}

\section{Funding}

The two authors are employed by German Federal Agency for Nature Conservation and were able to complete the article during their working hours at BfN. We appreciate funding support from BfN. The funding body had no impact on the design of the study, data interpretation, or the writing of the manuscript.

\section{Availability of data and materials}

For data used in the compilations of figures or as support for statements in the text, sources are given in the text or figure captions. No original data was collected for this article. Links to publicly available data can be found in the list of references.

Ethics approval and consent to participate Not applicable. 


\section{Consent for publication}

Not applicable.

\section{Competing interests}

The authors declare that they have no competing interests.

Received: 13 June 2019 Accepted: 9 March 2020

Published online: 18 March 2020

\section{References}

1. Schmidt C, Hofmann L, Dunkel A (2014) Den Landschaftswandel gestalten! Potentiale der Landschafts- und Raumplanung zur modellhaften Entwicklung und Gestaltung von Kulturlandschaften vor dem Hintergrund aktueller Transformationsprozesse. Band 1 Bundesweite Übersichten. https:// www.bfn.de/fileadmin/BfN/planung/landschaftsplanung/Dokumente/ Broschuere_LaWa_Band1.pdf. Accessed 14 Oct 2019

2. BMWi (2010) Energiekonzept für eine umweltschonende, zuverlässige und bezahlbare Energieversorgung. https://www.bmwi.de/Redaktion/DE/ Downloads/E/energiekonzept-2010.pdf?_blob=publicationFile\&v=3. Accessed 14 Oct 2019

3. Deutscher Bundestag (2018) Gesetz für den Ausbau erneuerbarer Energien (Erneuerbare-Energien-Gesetz - EEG 2017). https://www.gesetze-im-internet. de/eeg_2014/EEG_2017.pdf. Accessed 14 Oct 2019

4. United Nations (1992) Convention on Biological Diversity: CBD. https:// www.cbd.int/doc/legal/cbd-en.pdf. Accessed 14 Oct 2019

5. BMWi (2019) Time series for the development of renewable energy sources in Germany - based on statistical data from the Working Group on Renewable Energy-Statistics (AGEE-Stat). https://www.erneuerbare-energien. de/EE/Redaktion/DE/Downloads/zeitreihen-zur-entwicklung-dererneuerbaren-energien-in-deutschland-1990-2018-en.pdf;jsessionid=3725F5 7ED672FA45BEED1EA7654178D6?_blob=publicationFile\&v=6. Accessed 24 Sept 2019

6. BfN (2019) Erneuerbare Energien Report 2019. https://www.bfn.de/ fileadmin/BfN/erneuerbareenergien/Dokumente/ BfNErneuerbareEnergienReport2019_barrierefrei. Accessed 14 Oct 2019

7. Wietschel M, Plötz P, Pfluger B et al. (2018) Sektorkopplung - Definition, Chancen und Herausforderungen. https://www.isi.fraunhofer.de/content/ dam/isi/dokumente/sustainability-innovation/2018/WP01-2018_ Sektorkopplung_Wietschel.pdf. Accessed 24 Sept 2019

8. Bundesverband WindEnergie e. V. Windenergieanlagen in Deutschland. https:/www.wind-energie.de/themen/zahlen-und-fakten/deutschland/. Accessed 24 Sept 2019

9. Quaschning V (2019) Weltweite installierte Windkraftleistung. https:/www. volker-quaschning.de/datserv/windinst/index.php. Accessed 03 Dec 2019

10. Schmidt C (2015) Monitoring Kulturlandschaft Deutschland: Landschaften mit gravierendem Landschaftswandel seit 1996. https://tu-dresden.de/bu/ architektur/ila/lp/ressourcen/dateien/Forschung/abgeschlossene-forschung/ K3-0-0_Landschaftswandel_Gesamt.pdf?lang=de. Accessed 14 Oct 2019

11. Scheftelowitz M, Rensberg N, Denysenko V et al. (2015) Stromerzeugung aus Biomasse (Vorhaben Ila Biomasse): Zwischenbericht Mai 2015. https:// www.dbfz.de/fileadmin/eeg_monitoring/berichte/01_Monitoring_ZB_Mai_2 015.pdf. Accessed 14 Oct 2019

12. Schmidt C, Gagern M von, Lachor M et al. (2018) Landschaftsbild \& Energiewende. Grundlagen, vol 1. Bundesamt für Naturschutz, Bonn-Bad Godesberg

13. Fachagentur Nachwachsende Rohstoffe e. V. (2019) Basisdaten Bioenergie Deutschland 2019. https://www.fnr.de/fileadmin/allgemein/pdf/ broschueren/broschuere_basisdaten_bioenergie_2019_web.pdf. Accessed 24 Sept 2019

14. Kelm T, Metzger Jochen, Jachmann Henning, Günnewig D et al. (2019) Vorbereitung und Begleitung bei der Erstellung eines Erfahrungsberichts gemäß § 97 Erneuerbare- Energien-Gesetz: Teilvorhaben II c: Solare Strahlungsenergie. https://www.erneuerbare-energien.de/EE/Redaktion/DE/ Downloads/bmwi_de/zsv-boschundpartner-vorbereitung-begleitung-eeg. pdf?_blob=publicationFile\&v=7. Accessed 24 Sept 2019

15. Bruns $E$, Futterlieb M, Wenzel B et al. (2016) Instrumente für ein verbesserte räumliche Steuerung der Stromerzeugung aus erneuerbaren Energien. https://stiftung-umweltenergierecht.de/wp-content/uploads/2016/09/ stiftung_umweltenergierecht_endbericht_irsee_2017.pdf. Accessed 25 Sept 2019
16. Eichhorn M, Thylmann M, Peters W et al (2018) Spatial distribution of overhead power lines and underground cables in Germany in 2016. Data 3(3):34. https://doi.org/10.3390/data3030034

17. BfN (2011) Windkraft über Wald: Positionspapier des Bundesamtes für Naturschutz. https://www.bfn.de/fileadmin/MDB/documents/themen/ erneuerbareenergien/bfn_position_wea_ueber_wald.pdf. Accessed 14 Oct 2019

18. Peters $W$, Grunow $B$, Jennemann $L$ et al. (2011) Naturschutzstandards Erneuerbarer Energien: Schlussbericht. http://www.naturschutzstandardserneuerbarer-energien.de/images/stories/file/intern/110818_Endbericht\%2 ONatSchStandards\%20EE_final.pdf. Accessed 14 Oct 2019

19. Ammermann K, Ponitka J, Strauß C (2019) Combining climate protection and nature conservation: requirements for an environmentally friendly energy transition. In: Gawel E, Strunz S, Lehmann P et al (eds) The European Dimension of Germany's Energy Transition: Opportunities and Conflicts. Springer International Publishing, Cham, pp 311-333

20. UNFCCC (2015) Paris Agreement. https://unfccc.int/sites/default/files/ english_paris_agreement.pdf. Accessed 14 Oct 2019

21. BMUB (2015) Naturschutz-Offensive 2020 - Für biologische Vielfalt!

22. BMU, BfN (2018) Naturbewusstsein 2017 - Bevölkerungsumfrage zu Natur und biologischer Vielfalt. https://www.bmu.de/fileadmin/Daten_BMU/Pools/ Broschueren/naturbewusstseinsstudie_2017_de_bf.pdf. Accessed 14 Oct 2019

23. BfN (2018) BfN-Forschungsprogramm 2017 - 2021. https://www.bfn.de/ fileadmin/BfN/service/Dokumente/BfN-FP_2017-2021_Freigabe2018-07-23_ final_bf.pdf. Accessed 14 Oct 2019

24. Deutscher Bundestag (2017) Gesetz über Naturschutz und Landschaftspflege (Bundesnaturschutzgesetz): BNatSchG. https://www. gesetze-im-internet.de/bnatschg_2009/BNatSchG.pdf. Accessed 14 Oct 2019

25. AEE (2017) Grafik-Dossier zur jährlichen Aktzeptanzumfrage der Agentur für erneuerbare Energien. https:/www.unendlich-viel-energie.de/mediathek/ grafiken/grafik-dossier-zur-jaehrlichen-akzeptanzumfrage-der-agentur-fuererneuerbare-energien. Accessed 14 Oct 2019

26. Setton D, Matuschke I, Ortwin R (2018) Social sustainability barometer for the German Energiewende 2017: core statements and summary of the key findings. http://publications.iass-potsdam.de/pubman/item/escidoc:3 077889:6/component/escidoc:3077890/3077889.pdf. Accessed 14 Oct 2019

27. Hübner G, Pohl J, Warode J et al. (2019) Naturverträgliche Energiewende Akzeptanz und Erfahrungen vor Ort. https:/www.bfn.de/fileadmin/BfN/ biologischevielfalt/Bilder/PdM/2019_12/BfN-Broschuere_Akzeptanz_bf.pdf. Accessed 20 Dec 2019

28. Schmidt-Curreli J, Knebel A (2017) Energiewendeatlas Deutschland 2030 https:/www.unendlich-viel-energie.de/media/file/971.EWAtlas2017_Mai17_ web.pdf. Accessed 14 Oct 2019

29. Walter A, Wiehe J, Schlömer $\mathrm{G}$ et al. (2018) Naturverträgliche Energieversorgung aus $100 \%$ erneuerbaren Energien 2050. BfN-Skripten, vol 501. Bundesamt für Naturschutz, Bonn-Bad Godesberg

30. Wojtkiewicz W (2015) Sinn - Bild - Landschaft: Landschaftsverständnisse in der Landschaftsplanung ; eine Untersuchung von Idealvorstellungen und Bedeutungszuweisungen

31. Schmidt C, Gagern M von, Lachor M et al. (2018) Landschaftsbild \& Energiewende. Handlungsempfehlungen, vol 2. Bundesamt für Naturschutz, Bonn-Bad Godesberg

32. Plappert M-L, Rudolph M, Vollmer C (2019) Auswirkungen von Mindestabständen zwischen Windenergieanlagen und Siedlungen Auswertung im Rahmen der UBA-Studie "Flächenanalyse Windenergie an Land". https://www.umweltbundesamt.de/sites/default/files/medien/1410/ publikationen/2019-03-20_pp_mindestabstaende-windenergieanlagen.pdf. Accessed 14 Oct 2019

33. Lütkehus I, Salecker H, Adlunger K (2013) Potenzial der Windenergie an Land: Studie zur Ermittlung des bundesweiten Flächen- und Leistungspotenzials der Windenergienutzung an Land. https:/www. umweltbundesamt.de/sites/default/files/medien/378/publikationen/ potenzial_der_windenergie.pdf. Accessed 14 Oct 2019

34. BMVI (2015) Räumlich differenzierte Flächenpotentiale für erneuerbare Energien in Deutschland. https://www.bbr.bund.de/BBSR/DE/ Veroeffentlichungen/ministerien/BMVI/BMVIOnline/2015/DL_BMVI_Online_ 08_15.pdf?_blob=publicationFile\&v=2. Accessed 13 Dec 2019

35. Bofinger S (2012) Special Report Windpotentiale und Windflächen onshore. https://www.fraunhofer.de/content/dam/zv/de/forschungsthemen/energie/ Windreport-2011-de.pdf. Accessed 14 Oct 2019

36. FfE (2018) Regionalisierung des Ausbaus der erneuerbaren Energien: Begleitdokument zum Netzentwicklungsplan 2030 (V2019). https:/www. 
netzentwicklungsplan.de/sites/default/files/paragraphs-files/FfE_ Begleitstudie_Regionalisierung_EE-Ausbau_\%282018\%29_aktualisiert.pdf. Accessed 13 Dec 2019

37. FA Wind (2019) Überblick zu den Abstandsempfehlungen zur Ausweisung von Windenergiegebieten in den Bundesländern. https://www.fachagenturwindenergie.de/fileadmin/files/PlanungGenehmigung/FA_Wind_ Abstandsempfehlungen_Laender.pdf. Accessed 25 Sep 2019

38. AEE (2012) Forschungsradar Erneuerbare Energien - Studienvergleich: Entwicklung der Stromerzeugung aus Erneuerbaren Energien und des Strommixes in Deutschland. http://www.forschungsradar.de/fileadmin/ content/news_import/AEE_Dossier_Studienvergleich_EE-Erzeugung_ Strommix_feb12_01.pdf. Accessed 14 Oct 2019

39. Haller M, Repenning J, Vogel M et al. (2016) Überblick über vorliegende Szenarienarbeiten für den Klimaschutz in Deutschland bis 2050. https:// www.oeko.de/oekodoc/2445/2016-602-de.pdf. Accessed 14 Oct 2019

40. Buttler A, Spliethoff, Hartmut (2016) Kampf der Studien: Eine Metaanalyse aktueller Energiesystemstudien zum Bedarf an Speichern und konventionellen Kraftwerken im Kontext der Annahmen und der historischen Entwicklung. https://www.klimaschutz-niedersachsen.de/ Resources/Persistent/9b41ee59137f5a5497a610c876099825ac114842/TUM_2 01601 Kampf-der-Studien Metaanalyse.pdf. Accessed 26 Sept 2019

41. Schlesinger $M$, Hofer $P$, Kemmler A et al. (2010) Energieszenarien für ein Energiekonzept der Bundesregierung. https://www.ewi.uni-koeln.de/cms/ wp-content/uploads/2015/12/EWI_2010-08-30_Energieszenarien-Studie.pdf. Accessed 26 Sept 2019

42. Nitsch J, Pregger T, Naegler T et al. (2012) Langfristszenarien und Strategien für den Ausbau der erneuerbaren Energien in Deutschland bei Berücksichtigung der Entwicklung in Europa und global: Schlussbericht BMU - FKZ 03MAP146. http://www.fvee.de/fileadmin/publikationen/ Politische_Papiere_anderer/12.03.29.BMU_Leitstudie2011/BMU_Leitstudie2 011.pdf. Accessed 26 Sept 2019

43. Repenning J, Emele L, Blanck R et al. Klimaschutzszenario 2050: 2. Endbericht. https://www.oeko.de/oekodoc/2451/2015-608-de.pdf. Accessed 26 Sept 2019

44. BfN (2018) Naturschutz und Erneuerbare Energien: Forschung im BfNThemenschwerpunkt. https:/www.natur-und-erneuerbare.de/fileadmin/ Daten/Download_Dokumente_bf/2018_Naturschutz_und_erneuerbare_ Energien_Broschuere_BfN_barr.pdf. Accessed 14 Oct 2019

45. Roth M, Röhner S, Tilk C et al. (2018) Bundesweite GIS-basierte Landschaftsbildbewertung als Beitrag zur Umweltprüfung im Zuge des Stromnetzausbaus. In: Strobl J, Zagel B, Griesebner G et al. (eds) AGIT : Journal für Angewandte Geoinformatik. Wichmann, Berlin, pp 415-424

46. Eichhorn M, Scheftelowitz M, Reichmuth M et al (2019) Spatial Distribution of Wind Turbines, Photovoltaic Field Systems, Bioenergy, and River Hydro Power Plants in Germany. Data 4(1):29. https://doi.org/10.3390/data4010029

47. Bernotat D, Dierschke V (2016) Übergeordnete Kriterien zur Bewertung der Mortalität wildlebender Tiere im Rahmen von Projekten und Eingriffen. http://www.gavia-ecoresearch.de/ref/pdf/Bernotat_Dierschke_2016.pdf. Accessed 14 Oct 2019

48. LAG VSW (2015) Recommendations for distances of wind turbines to important areas for birds as well as breeding sites of selected bird species (as at April 2015). http://www.vogelschutzwarten.de/downloads/lagvsw2015. pdf. Accessed 14 Oct 2019

49. Lachmann L (2019) Der Rotmilan und die Windenergie: problem wegdiskutieren oder lösen?: Stellungnahme Rotmilan und Windenergie vom 05.09.2019. https://www.nabu.de/downloads/vogelschutz/ Stellungnahme\%20NABU\%20Rotmilan\%20Artenschutz\%20WEA_Sep2019 final_layouted.pdf. Accessed 17 Dec 2019

50. Nagel H, Nicolai B, Mammen U et al (2019) Verantwortungsart Rotmilan Ermittlung von Dichtezentren des Greifvogels in Sachsen-Anhalt. Naturschutz und Landschaftsplanung 51:14-19

51. Ministerium für Umwelt, Landwirtschaft und Energie des Landes SachsenAnhalt (2018) Leitfaden Artenschutz an Windenergieanlagen in SachsenAnhalt. https://mule.sachsen-anhalt.de/fileadmin/Bibliothek/Politik_und_ Verwaltung/MLU/MLU/04_Energie/Erneuerbare_Energien/Windenergie/1 81126_Leitlinie_Artenschutz_Windenergieanlagen_barrierefrei.pdf. Accessed 19 Dec 2019

52. Blew J, Albrecht K, Reichenbach M et al. (2018) Wirksamkeit von Maßnahmen gegen Vogelkollisionen an Windenergieanlagen: Methodenentwicklung für artenschutzrechtliche Untersuchungen zur Wirksamkeit von Vermeidungs- und Minderungsmaßnahmen zur
Reduzierung der Auswirkungen von Windenergieanlagen auf die Avifauna. https:/www.bfn.de/fileadmin/BfN/service/Dokumente/skripten/Skript518. pdf. Accessed 14 Oct 2019

53. Berr K, Jenal C (eds) (2019) Landschaftskonflikte. Springer Vieweg. in Springer Fachmedien Wiesbaden GmbH, Wiesbaden, GERMANY

54. Roth M (2018) Landschaftsplanung meets Energiewende. In: Marschall I (ed) Landschaftsplanung im Prozess und Dialog: Beiträge zur gemeinsamen Fachtagung von BfN, BBN und FH Erfurt vom 27.03.-29.03.2017 in Erfurt. BfN, Bonn, pp 114-126

55. Roth M, Hildebrandt S, Röhner S et al. (2018) Landscape as an area as perceived by people: empirically-based nationwide modelling of scenic landscape quality in Germany. In: Buhmann E (ed) Journal of Landscape Architecture, 1. Neuerscheinung. VDE VERLAG, Berlin, pp 129-137

56. Schwarzer M, Mengel A, Konold W et al. (2018) Bedeutsame Landschaften in Deutschland Gutachtliche Empfehlungen für eine Raumauswahl: Band 1: Schleswig-Holstein und Hamburg, Niedersachsen und Bremen, Mecklenburg-Vorpommern, Nordrhein-Westfalen, Sachsen-Anhalt, Brandenburg und Berlin. https://www.bfn.de/fileadmin/BfN/service/ Dokumente/skripten/Skript516.pdf. Accessed 14 Oct 2019

57. Schwarzer M, Mengel A, Konold W et al. (2018) Bedeutsame Landschaften in Deutschland Gutachtliche Empfehlungen für eine Raumauswahl: Band 2: Rheinland-Pfalz, Saarland, Hessen, Thüringen, Sachsen, Baden-Württemberg, Bayern. https://www.bfn.de/fileadmin/BfN/service/Dokumente/skripten/ Skript517.pdf. Accessed 14 Oct 2019

58. Marques AT, Batalha H, Rodrigues S et al (2014) Understanding bird collisions at wind farms: an updated review on the causes and possible mitigation strategies. Biological Conservation 179:40-52. https://doi.org/10. 1016/j.biocon.2014.08.017

59. Dürr T (2019) Vogelverluste an Windenergieanlagen in Deutschland: Daten aus der zentralen Fundkartei der Staatlichen Vogelschutzwarte im Landesamt für Umwelt Brandenburg (as of 07.01.2019). https://ffu. brandenburg.de/cms/media.php/lbm1.a.3310.de/wka_voegel_de.xls. Accessed 14 Oct 2019

60. Korner-Nievergelt F, Brinkmann R, Niermann I et al (2013) Estimating bat and bird mortality occurring at wind energy turbines from covariates and carcass searches using mixture models. PLoS ONE 8(7):e67997. https://doi. org/10.1371/journal.pone.0067997

61. Mammen U, Nicolai B, Böhner J et al. (2014) Artenhilfsprogramm Rotmilan des Landes Sachsen-Anhalt. https://lau.sachsen-anhalt.de/fileadmin/ Bibliothek/Politik_und_Verwaltung/MLU/LAU/Naturschutz/Publikationen/ Dateien/berichte_5-14_ahp-rotmilan.pdf. Accessed 19 Dec 2019

62. Erneuerbare im naturschutzfachlichen Monitoring. https://www.ufz.de/eemonitor-app/. Accessed 02 Oct 2019

63. BMUB, BfN (2017) 5-Punkte-Papier für eine naturverträgliche Energiewende. https://www.bmu.de/fileadmin/Daten_BMU/Download_PDF/Naturschutz/5_ punkte_energiewende_bf.pdf. Accessed 14 Oct 2019

64. Mai T, Logan J, Blair N et al. (2013) RE-ASSUME: a decision maker's guide to evaluating energy scenarios, modeling, and assumptions

65. WWF Deutschland (ed) (2019) ZUKUNFT STROMSYSTEM II - Regionalisierung der erneuerbaren Stromerzeugung: Vom Ziel her denken, Berlin

66. Gauglitz P, Schicketanz S, Pape C (2019) Nature conservation as a driver in wind energy scenarios. Energ Sustain Soc 9(1):437. https://doi.org/10.1186/ s13705-019-0233-0

67. Research on the inclusion of nature conservation in the energy transition in Germany. https://www.natur-und-erneuerbare.de/english/. Accessed 25 Sept 2019

\section{Publisher's Note}

Springer Nature remains neutral with regard to jurisdictional claims in published maps and institutional affiliations. 